\title{
Effect of freezing on the initial colonization of the carcass with necrophagous organisms
}

\author{
Hana Šuláková, Lucie Harakalová \& Miroslav Barták
}

\begin{abstract}
Effect of freezing on the initial colonization of the carcass with necrophagous organisms. - Acta Mus. Siles. Sci. Natur., 63: 28-37, 2014.

Abstract: This study was aimed to determine whether freezing of cadaver prior to the free exposure affects the species composition and the rate of its initial colonization with necrophagous organisms. Two experiments were realized in Smečno town, the Central Bohemian Region of the Czech Republic, in which carcasses of domestic fowl (Gallus gallus f. domestica L.) weighing about $1.5 \mathrm{~kg}$ were obtained and treated the same way, only half of them were frozen before exposure in June and July 2013. Pre-frozen and fresh carcasses colonized the same kinds of blowflies (Diptera, Calliphoridae): Calliphora vicina Robineau-Desvoidy, 1830, Lucilia sericata (Meigen, 1826), Lucilia illustris (Meigen, 1826), Lucilia ampullacea Villeneuve, 1922, Phormia regina (Meigen, 1826), and Protophormia terraenovae (Robineau-Desvoidy, 1830). Percentage rate of each species was almost the same in both versions but we found differences in the total number of individuals (larvae) decomposing carcasses and differences in the process of decomposition of carcasses: fresh carcass decomposition was predominantly anaerobic (putrefaction) and started from the digestive system to the outside of the body (inside-out). Pre-frozen carcasses decomposed predominantly aerobic (decay) and started from the surface of body inwards (outside-in). Utilization of our results in forensic practice is discussed.
\end{abstract}

Key words: forensic entomology, carcass, Calliphoridae, freezing, insect colonization.

\section{Introduction}

In forensic practice, we encounter cases where the human body, eventually its parts, the perpetrator keeps for some time in the freezer before tossing or burial in nature. A question whether it is possible to distinguish carcasses "fresh" from carcasses that had been previously frozen by methods of forensic entomology arises. Information about previous freezing could be of great importance both for the process of investigation and determining the correct post mortem interval. The period of invertebrate activity on a dead body is logically shorter than the actual post mortem interval just about time that the corpse was stored in unfavourable conditions for insects. The aim of the study was to determine by a field experiment whether "fresh" and "pre-frozen" carcasses differ in speed of the first colonization by necrophagous organisms and if it is possible to use the species composition of necrophagous fauna in recognizing previous freezing.

The rate of development of necrophagous community, its species composition, the rate of decomposition, and the development of successional waves are influenced by many factors, including the "status" of corpses, temperature and humidity conditions, habitat, and influence of other organisms (Šuláková 2006), the most important being the ambient temperature during decomposition (Byrd \& Castner 2010). The first necrophagous species that in the Czech Republic participate in the desintegration of corpses are flies of the family Calliphoridae (Daněk 1990, Povolný 1979). This dipteran family includes forensically the most important necrophagous organisms (Byrd \& Castner 2010, Stmith 1986), so a number of studies was focused on the effect of temperature on development cycles of blowflies (e.g. Anderson 2000, Marchenko 2001), blowfly year activity and seasonality (e.g. Arnaldos et al. 2004, Klotzbach et al. 2003, Schroeder et al. 2003), and the thermal resistance of eggs, larvae and puparia or supercooling effect on the subsequent development (e.g. Block et al. 1990, Huntington et al. 2007, Johl \& Anderson 1996) in order to minimize errors in calculating the post mortem 
interval. The subject of research was also the influence of frozen-thawed meat as feed substance in rearing larvae in the laboratory on the length of development cycles (e.g. Day \& Wallmann 2006).

As the first, Micozzi (1986) conducted a series of experiments in which he compared decomposition of freshly killed and frozen-thawed cadavers. His experiments showed that the freshly killed animal passes through typical anaerobic decomposition (putrefaction), which starts in the digestive tract by bacterial action. Gas produced by enteric flora inflates the carcass and pushes bacteria into the rest of the body, which then degrades the blood and other tissues. The degradation process is thus directed from inside the body outwards ("inside-out"). In contrast, the frozen carcass thaws from the surface inwards and then its gastrointestinal tract and internal organs are released last. For this reason, the bacteria in the digestive tract are "excluded" from the degradation process at first. Previous freezing also cause mechanical disruption of the skin and other body cells by growing ice crystals so for frozen carcass is dominant aerobic decomposition (decay) caused by microorganisms from the external environment which process continues towards the inside of the body ("outside-in"). Micozzi (1986) recommended to use only the freshly slaughtered or dead animals in forensic entomological studies and the results obtained from animals after thawing apply only to human bodies found after the winter period or under similar conditions (e.g. on glaciers).

In spite of previous research, data from experiments comparing colonization of fresh and frozen-thawed cadavers are still scarce. Mise et al. (2013) found that the prior freezing may reduce the number of beetle species that colonize the carcass after thawing. For members of the family Calliphoridae, it is assumed, that they do not participate in the decomposition process in the temperate zone during the cold part of the year (Smith 1986). An exception may be the genus Calliphora Robineau - Desvoidy, 1830 which imaga were found to be active during the winter in the temperature range of -7 to $+5^{\circ} \mathrm{C}$ but only under sunny conditions (Deonier 1940, Nuorteva 1959). Higher tolerance of flies of the genus Calliphora to low temperatures may also be demonstrated by finding corpses at high altitudes (above the tree line; Adair 2008, Adair \& Kondratieff 2006, Faucherre et al. 1999) or in caves in the dark under year-round temperature of about $5{ }^{\circ} \mathrm{C}$ (Faucherre et al. 1999). Wyss et al. (2003) observed blowflies ovipositing on a frozen corpse which lay under a layer of snow on the firn field; females visited the body through the tunnel, which was created by melting the snow over the head of the dead.

\section{Material and methods}

\section{Experimental area}

Experiments with a free exposition of carcasses were held in the garden of a family house in Smečno town, located in the Central Bohemian Region of the Czech Republic (GPS: 50¹1'17" N, 14²'31" E; $372 \mathrm{~m}$ a.s.l). The garden is planted with ornamental flowers and fruit trees and also includes a small water body. The surrounding lands are composed of extensive gardens.

\section{Description of experiments and collecting methods}

Four carcasses of domestic fowl (Gallus gallus f. domestica L.) were used each weighing some $1.5 \mathrm{~kg}$. All individuals were killed in the same way (decapitated) and the head was left with the rest of the carcass. Two individuals were killed on May 192013 and stored in a freezer at $-22{ }^{\circ} \mathrm{C}$ until the beginning of the experiments in order to complete freezing. The other two individuals were killed at the beginning of each experiment. Two replicates of both variants (frozen and fresh) were carried out, each with one frozen and one freshly killed animal. The first exposition of carcasses began June 23 2013, the second July 292013.

At the beginning of the experiment were frozen and freshly slaughtered individuals simultaneously put separately into plastic boxes and then exposed in the experimental area to free access of insects. To protect them against vertebrates (cats, rodents, etc.) both containers with carcasses were placed in wire cage (Fig. 1). The upper part of the cage was covered with a plastic sheet to protect the test subjects from rainfall (the cover did not prevent invertebrate activity). Cadavers were freely exposed four days (first set) due to the bad weather conditions (rain, low temperatures - see tab. 1) and two days (second set). In both series, the free exposition 
finished after the first larvae were observed. Subsequently, the plastic boxes were transferred to a room without windows. About $5 \mathrm{~cm}$ layer of sand was added to each box for enabling pupation and boxes were covered with fine fabric enabling ventilation but preventing access of insects.

After all larvae pupated, the remnants of carcasses were removed and containers were fitted with the trapping device which automatically captured newly hatched adults (Fig. 2). Trapping bottle was filled with a solution consisting of 2 litres of water, $2 \mathrm{ml}$ of 38-40\% formaldehyde and $1 \mathrm{ml}$ of a detergent. The adults were collected from trapping bottle daily and stored in $70 \%$ ethanol.

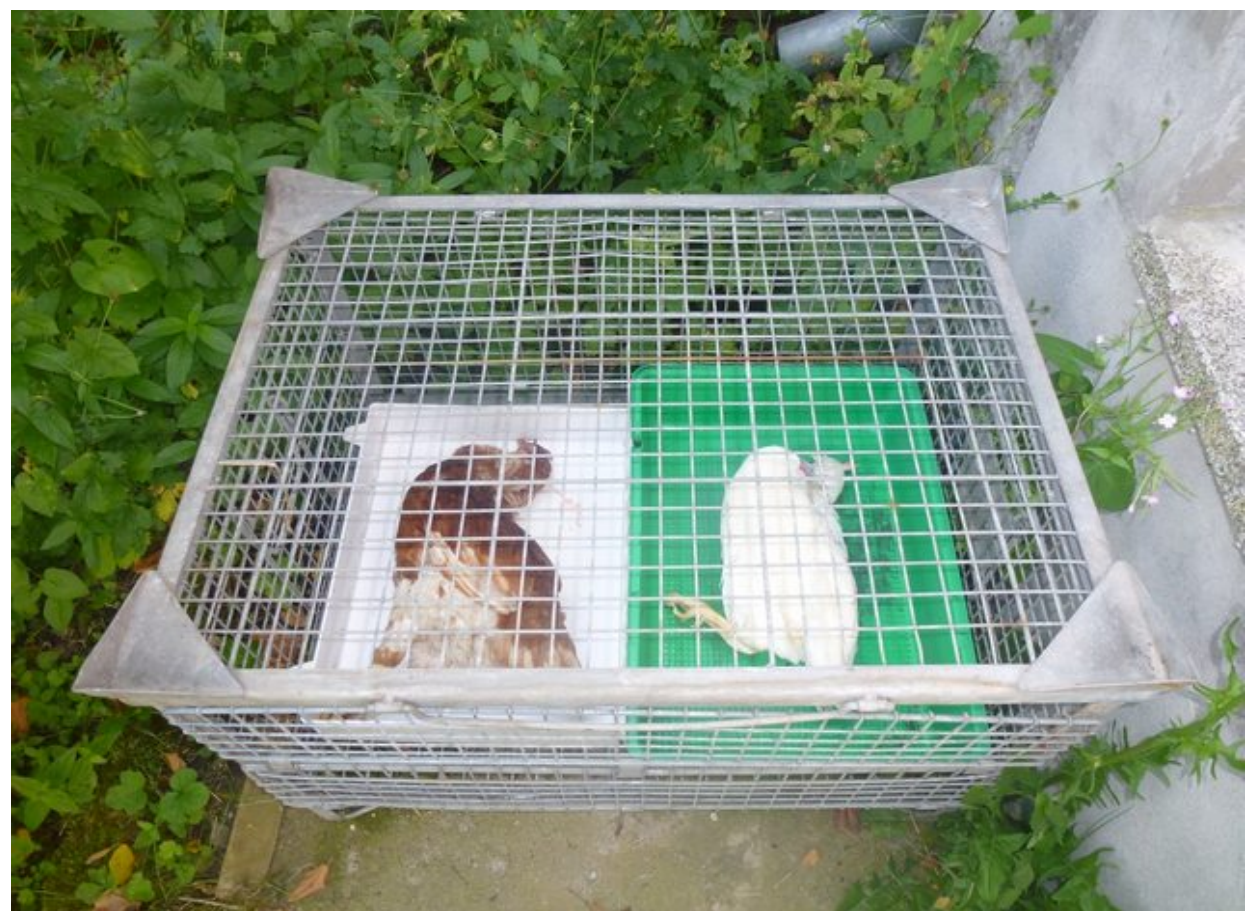

Fig. 1: Free exposition of fresh (left) and frozen (right) cadaver in a wire cage. (All photos by Lucie Harakalová)

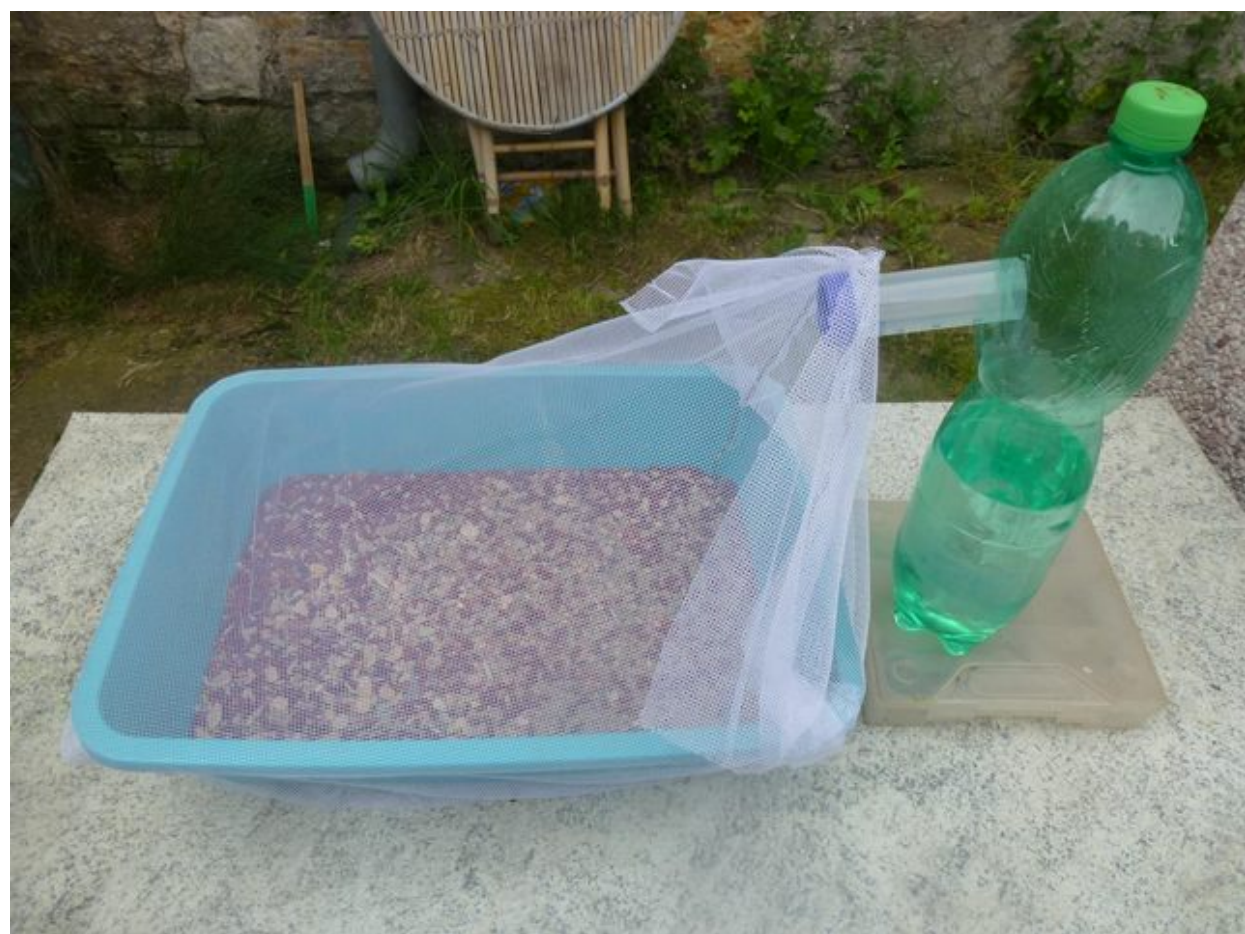

Fig. 2: Breeding box with device trapping hatched adults. 
Tab. 1: Climatic conditions in the days of the free outdoor exposition of fresh and frozen carcasses.

\begin{tabular}{|l|c|c|c|c|c|c|}
\hline & \multicolumn{4}{|c|}{ Replicate 1 } & \multicolumn{2}{c|}{ Replicate 2 } \\
\hline $\begin{array}{l}\text { Order of the } \\
\text { day }\end{array}$ & 1. & 2. & 3. & 4. & 1. & 2. \\
\hline Date (2013) & 23.6. & 24.6. & 25.6. & 26.6. & 29.7. & 30.7. \\
\hline T max & $25.1^{\circ} \mathrm{C}$ & $17^{\circ} \mathrm{C}$ & $15^{\circ} \mathrm{C}$ & $12.6^{\circ} \mathrm{C}$ & $34.8^{\circ} \mathrm{C}$ & $28.1^{\circ} \mathrm{C}$ \\
\hline Humidity & $64 \%$ & $95 \%$ & $90 \%$ & $66 \%$ & $71 \%$ & $75 \%$ \\
\hline Rainfall & $0 \mathrm{~mm}$ & $7.6 \mathrm{~mm}$ & $21 \mathrm{~mm}$ & $1 \mathrm{~mm}$ & $0 \mathrm{~mm}$ & $0 \mathrm{~mm}$ \\
\hline Air speed & $10.8 \mathrm{~km} / \mathrm{h}$ & $18 \mathrm{~km} / \mathrm{h}$ & $2 \mathrm{~km} / \mathrm{h}$ & $2 \mathrm{~km} / \mathrm{h}$ & $10.8 \mathrm{~km} / \mathrm{h}$ & $28.8 \mathrm{~km} / \mathrm{h}$ \\
\hline Air pressure & $1014 \mathrm{hPa}$ & $1016 \mathrm{hPa}$ & $1018.4 \mathrm{hPa}$ & $1022.8 \mathrm{hPa}$ & $1009.6 \mathrm{hPa}$ & $1010.9 \mathrm{hPa}$ \\
\hline
\end{tabular}

\section{Material}

Identification of adult flies was performed using keys by Rognes (1991) and Draber-Mońko (2004). Nomenclature was taken from Fauna Europaea database (Rognes 2013). Specimens were identified by the senior author (HS).

\section{Meteorological data}

Data on temperature, humidity, rainfall, and air flow and pressure were recorded using a meteorological station SENCOR SWS270 (PRC).

\section{Results}

Only representatives of dipteran family Calliphoridae initially colonized all carcasses. In the first experiment, the two carcasses (i.e. fresh and frozen) were colonized with the following species: Calliphora vicina Robineau-Desvoidy, 1830 (83.1 \% and $82.7 \%$, respectively), Lucilia sericata (Meigen, 1826) (14.6\% and $14.8 \%$, respectively), and Lucilia illustris (Meigen, 1826) (Fig. 3). Beside them, an additional species, Lucilia ampullacea Villeneuve, 1922 (58.0 \% and $44.0 \%$, respectively; see Fig. 3), was involved in decomposition of the frozen cadaver (Figs 3-4). The total number of captured adults is presented in Fig. 4.

In the second series, the two carcasses (i.e. fresh and frozen) were colonized with the following species: Lucilia sericata (98.6 \% and $94.6 \%$, respectively), Phormia regina (Meigen, 1826) and Protophormia terraenovae (Robineau-Desvoidy, 1830) (Fig. 5). The number of adults reared from fresh and frozen carcass at the second set is presented in Fig. 6 .

The first blowfly activity was recorded in both series during the first or second day. For the second replicate, with more suitable climatic conditions for insects (higher temperatures, periods without rainfall - see Tab. 1), the first blowflies on cadavers appeared within a few minutes after the exposition.

On both fresh cadavers, blow fly females lay their eggs especially around the anal orifice and subsequent decomposition progressed from the anus to the head and the activity of larvae proceeded from inside-out. In both replicates larvae accumulated on the lower surfaces (in ground contact). The number of eggs and subsequently of larvae on fresh cadavers was so high that their action destroyed almost all soft tissues of animals. In the second set, typical signs of competition for food were also reported, i.e. higher mortality of larvae and hatched adults reached only $1 / 2$ to $2 / 3$ of normal size. 


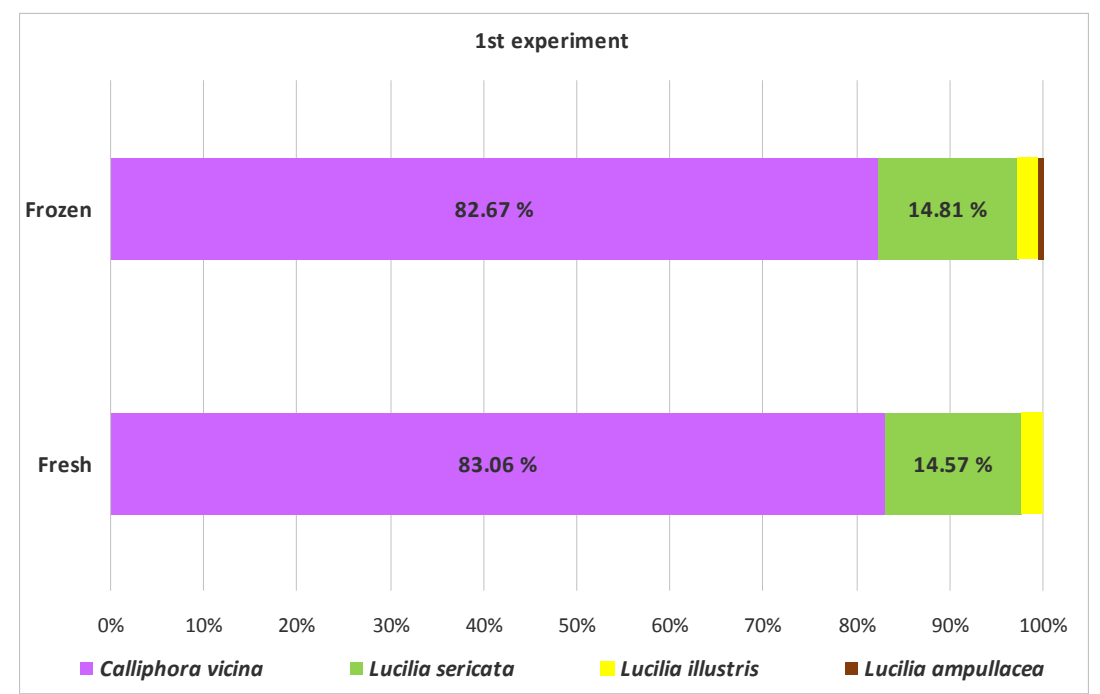

Fig. 3: Percentage ratio of species involved in the decomposition of the fresh and frozen carcass at the first replicate.

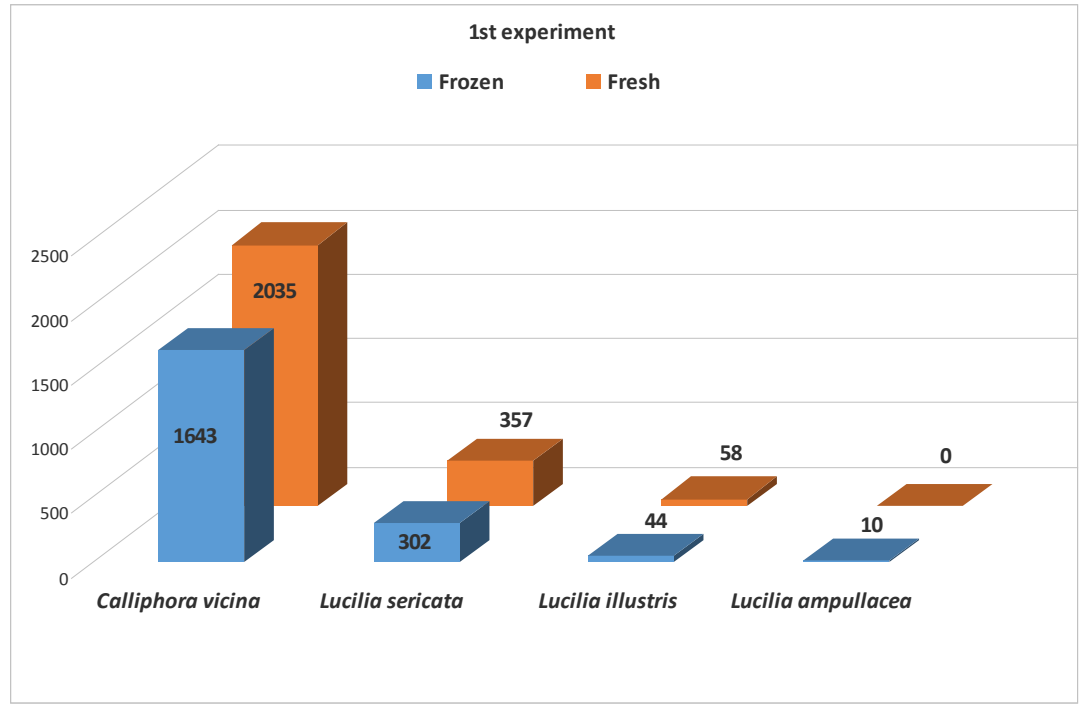

Fig. 4: Number of adults of individual species reared from the first replicate.

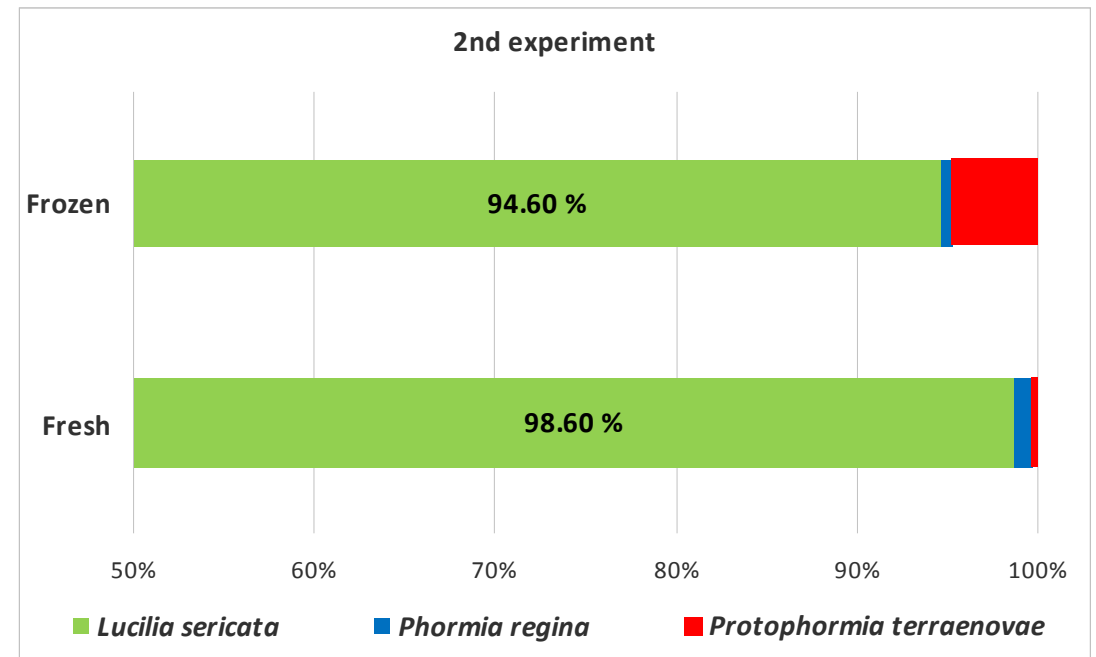

Fig. 5: Percentage ratio of the species involved in the decomposition of the fresh and frozen carcass at the second replicate (for easier visualization of a minority species the chart scale is represented up from 50 $\%)$. 
On the frozen carcasses, blow fly females lay their eggs in the bloodiest areas of the head and neck. Comparing the decay of both frozen cadavers, small differences in location of larval accumulations were observed. In the first replicate, the majority of larvae accumulated on the upper surface of the body (exposed to air) whereas during the second replicate maggot mass formed on the side adjacent to the ground. Subsequent decomposition of both frozen specimens already progressed similarly from the neck caudally and simultaneously from the body surface inside (outside-in). Anal area of both frozen animals remained practically intact in time of pupation and about one-third of soft tissue left on both frozen-thawed carcasses. In frozen variants, there were always lower number of individuals of the dominant species (Figs 4 and 6).

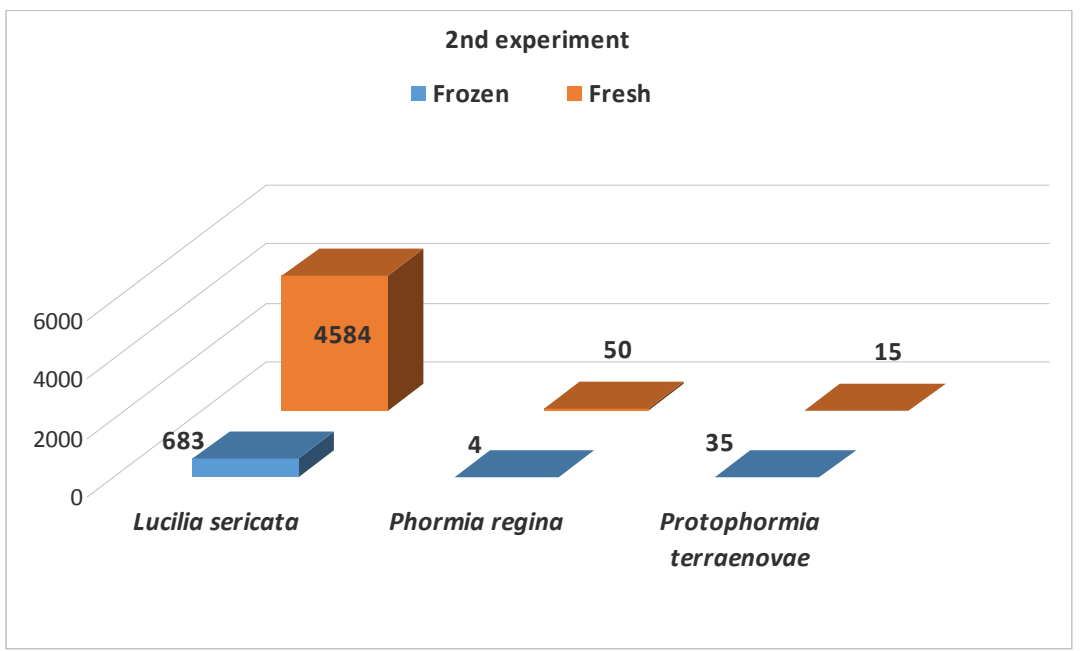

Fig. 6: Number of adults of individual species reared from the second replicate.

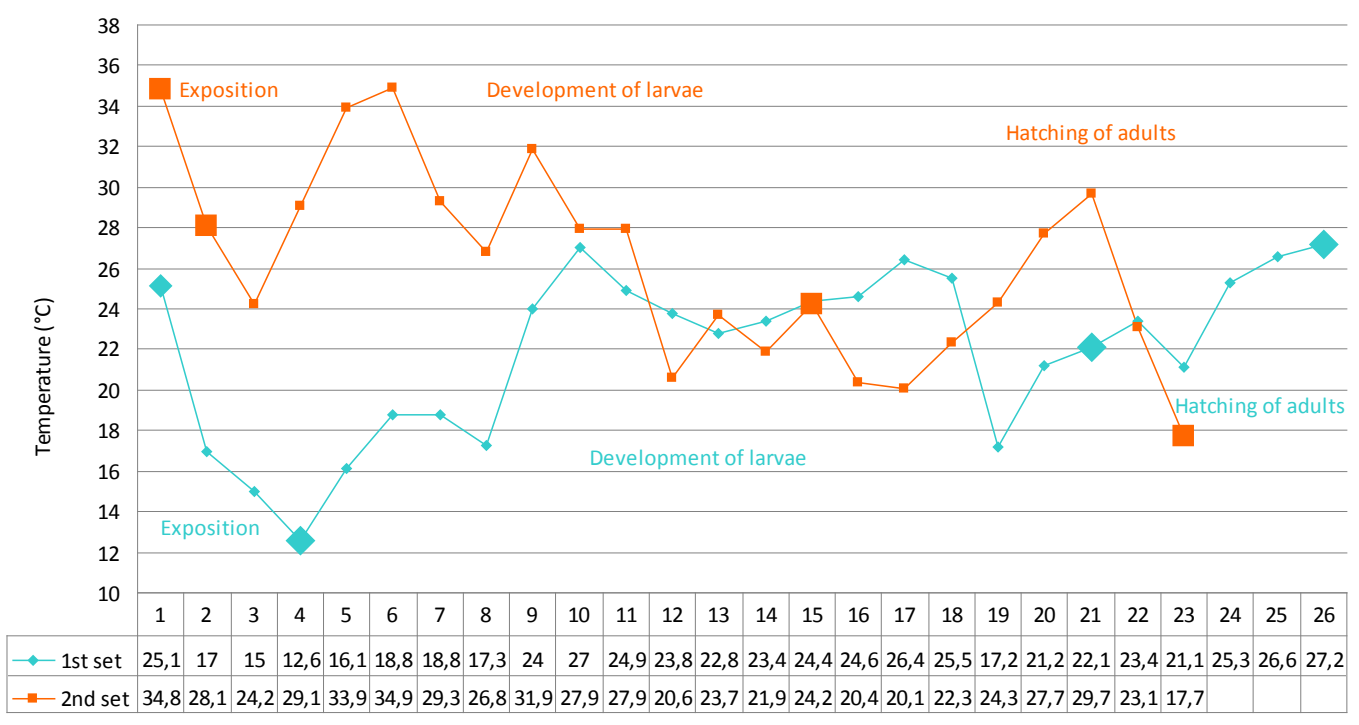

Fig. 7: Comparison of daily temperatures during the first and second replicates showing the individual phases of both experiments (bigger squares and rhombuses define beginnings and ends of periods: exposition - development of larvae - hatching of adults).

\section{Discussion and conclusions}

On decomposition of both carcasses, fresh and frozen, only flies of the family Calliphoridae (Diptera) participated, namely Calliphora vicina, Lucilia sericata, Lucilia illustris, Lucilia ampullacea, Phormia regina a Protophormia terraenovae. The dominance of Calliphora vicina during the first experiment may be explained by the climatic conditions 
prevailing during the trial and temperature preference and tolerance of the species (Hwang \& Turner 2005, Smith 1986). Surprising was, however, a high proportion of the species Lucilia sericata in both experiment and both variants. In the first set, and despite the low temperature and high precipitation, this thermophilic species (Povolný 1979) represented in both variants almost $15 \%$ of reared adults (Fig. 3). In the second replicate this species represented nearly $99 \%$ and $95 \%$ of all adults, respectively, obtained from fresh and frozen cadavers (see Fig. 5). We disagree with the statement of Povolný (1979) that Lucilia sericata oviposits exclusively on the substrate with surface temperature at least $30{ }^{\circ} \mathrm{C}$, which in the Czech Republic assumes only ovipositing on fresh-killed or fresh-dead carcass or after prolonged period of direct sunlight, alternatively. Our results show that Lucilia sericata lays its eggs on the substrate at a lower temperature and does not avoid frozen carcasses. These findings correspond with data known from human bodies in the Czech Republic (Šuláková, unpublished). However, we agree with Cragg (1956), that the substrate temperature of 30-40 ${ }^{\circ} \mathrm{C}$ significantly increases oviposition rate which is documented by greatly different number of individuals reared from fresh and frozen carcasses during the second trial $(4,584$ individuals against 683; see Fig. 6).

Percentage of other, minor species, in both variants (fresh vs. frozen carcass) was comparable (Figs 3 and 5). Only in Protophormia terraenovae, it is not clear whether its higher representation on the frozen variant (Fig. 5) was associated with female oviposition preference for the frozen carcass or with a lower competition capabilities with the species Lucilia sericata on the fresh cadaver.

We did not confirm the conclusions of Mise et al. (2013) that freezing/thawing reduces the number of species on the carcasses. On the contrary, we noticed in frozen alternative an additional species, Lucilia ampullacea, that was absent from fresh carcasses. Nevertheless, with regard to the small numbers of adults (10 specimens, see Fig. 4), we cannot unambiguously confirm that freezing had an effect of increasing diversity. This fact should be verified by additional experiments.

The results of our experiments confirmed the results of Micozzi (1986) that there is a difference between fresh and frozen carcass in the process of decomposition of their bodies. Fresh carcass decomposition started from the gastrointestinal tract and proceeds towards the outer parts of body ("inside-out"). Frozen carcass started decomposition on the body surface which had thawed first. Blow fly females responded to this by laying eggs just on the bloody places. Subsequent decomposition was directed from the surface of the body inside ("outsidein") as Micozzi (1986) reported.

Our experiments showed that the "rate of colonization" (i.e. the time interval between exposition of cadavers and the first activity of flies) was not significantly different between fresh and frozen cadavers. Only during the first replicate of the experiment, we observed first activity on the fresh cadaver and only after a few hours on frozen one. This delay was also reflected in the subsequent development of larvae, their pupation, and hatching of adults which were observed on frozen carcass a day later than on fresh one. The difference might be caused not only by the freezing of the animal but could be attributed to poorer weather conditions during the first trial (Tab. 1 and Fig. 7) or to lower activity of insects under these conditions or to much slower thawing of the frozen carcass. During the second experiment (better weather conditions) similar delay was not observed. We cannot confirm the observation of Micozzi (1986) that the frozen carcass decomposes faster. In our experiments, focused only on the first colonizers, pre-frozen carcasses left much more soft tissue than fresh ones but it could be due to the smaller number of larvae that have contributed to the degradation (Figs 4 and 6).

The results so far show that "species composition" and "percentage rates" of firstly arrived necrophagous insects (i.e. flies of the family Calliphoridae) is similar in both fresh and 
frozen carcasses. Therefore, the evaluation of the presence / absence of these early colonizers probably cannot be used to prove the previous storing of the body in a freezer. Similar results were obtained also when compared the "speed of colonization" of carcasses, which, especially at higher (optimal) temperatures, were almost identical.

Current data suggest that for the proof of pre-freezing we could use the number of specimens (of larvae) participating in the decomposition. In both replicates we found that the fresh carcass was always more heavily infested than frozen. In our opinion, it is necessary to evaluate only the dominant species presence because minor species may occur only by chance. Nevertheless, this method of identifying previously frozen carcass alludes to the fact that the number of ovipositing females or eggs and subsequently active larvae affects not only the "state" of the corpse but a number of other factors as well (Šuláková 2006). This is evidenced by our results when under the optimal conditions (high temperatures at the second replicate) the number of individuals who have completed the development was much higher in the case of fresh carcass (4,649 specimens in comparison to 722), however, this ratio was significantly decreased at the second experiment during lower air temperatures $(2,450$ specimens to 1,999 specimens again in favor of fresh-killed variant).

The most obvious differences between fresh and frozen variants were observed comparing the process of decomposition ("outside-in" vs. "inside-out"). However, the degradation process is appreciable and practically applicable only in the early stages of degradation when there is still a sufficient amount of soft tissue on the body. After skeletonization (by action of necrophages) this method is useless in practice already. We assume that it cannot be also used where the initial stage of decomposition in the digestive tract is impossible, for example if only separate body parts are found (e.g. limbs). For the final confirmation of the effect of freezing prior to the subsequent colonization with insects we need additional series of experiments.

Acknowledgements: The project was financially supported by project No. VF20102014001 of the Ministry of the Interior of the Czech Republic (HS) and S grant of the Ministry of Education, Sports and Youth (MB, LH).

\section{References}

Adair T.W. (2008): Calliphora vicina (Diptera: Calliphoridae) Collected from a Human Corpse Above $3400 \mathrm{~m}$ in Elevation. - Journal of Forensic Science 53(5): 1212-1213.

Adair T.W. \& Kondratieff B.C. (2006): Three Species of Insects Collected from an Adult Human Corpse Above $3300 \mathrm{~m}$ in Elevation: A Review of a Case from Colorado. - Journal of Forensic Science 51(5): 1164-1165.

Anderson G.S. (2000): Minimum and Maximum Development Rates of Some Forensically Important Calliphoridae (Diptera). - Journal of Forensic Science 45(4): 824-832.

Arnaldos M.I., Romera E., Presa J.J., Luna A. \& García M.D. (2004): Studies on seasonal arthropod succession on carrion in the southeastern Iberian Peninsula. - International Journal of Legal Medicine 118: 197-205.

Block W., Erzinclioglu Y.Z. \& Worland M.R. (1990): Cold resistance in all life stages of two blowfly species (Diptera, Calliphoridae). - Medical and Veterinary Entomology 4: 213-219.

Byrd J.H. \& Castner J.L. (eds) (2010): The Utility of Arthropods in Legal Investigations. Forensic Entomology. 2nd ed. CRC Press, Boca Raton FL, 681 pp.

Cragg J.B. (1956): The olfactory behaviour of Lucilia species (Diptera) under natural conditions. - Annals of Applied Biology 44: 467-477.

Daněk L. (1990): Možnosti využití entomologie v kriminalistice. Kriminalistický ústav VB, Praha, 144 pp.

Day D.M. \& Wallman J.F. (2006): A comparison of frozen/thawed and fresh food substrates in development of Calliphora augur (Diptera: Calliphoridae) larvae. - International Journal of Legal Medicine 120: 391394.

Deonier C.C. (1940): Carcass temperatures and their relation to winter blowfly populations and activity in the Southwest. - Journal of Economic Entomology 33(1): 166-170.

Draber-Mońko A. (2004): Calliphoridae. Plujky (Insecta: Diptera). Fauna Polski 23, Warszawa, 662 pp. 
Faucherre J., Cherix D. \& Wyss C. (1999): Behavior of Calliphora vicina (Diptera, Calliphoridae) under extreme conditions. - Journal of Insect Behavior 12: 687-690.

Huntington T.E., Higley L.G. \& Baxendale F.P. (2007): Maggot Development During Morgue Storage and Its Effect on Estimating the Post-Mortem Interval. - Journal of Forensic Science 52(2): 453-458.

Hwang C. \& Turner B.D. (2005): Spatial and temporal variability of necrophagous Diptera urban to rural areas. - Medical and Veterinary Entomology 19: 379-91.

Johl H.K. \& Anderson G.S. (1996): Effects of refrigeration on development of the blow fly Calliphora vicina (Diptera: Calliphoridae) and their relationship to time of death. - Journal of the Enomological Society of British Columbia 93: 93-98.

Klotzbach H., Püschel K. \& Schroeder H. (2003): Insects colonization of human corpus in warm and cold season. - Legal medicine 5: 372-374.

Marchenko M.I. (2001): Medicolegal relevance of cadaver entomofauna for the determination of the time of death. - Forensic Science International 120: 89-109.

Micozzi M.S. (1986): Experimental Study of Postmortem Change Under Field Conditions: Effects of Freezing, Thawing, and Mechanical Injury. - Journal of Forensic Science 31(3): 953-961.

Mise K.M., Corrêa R.C. \& Almeida L.M. (2013): Coleopterofauna found on fresh and frozen rabbit carcasses in Curitiba, Paraná, Brazil. - Brazilian Journal of Biology 73(3): 543-548.

Nuorteva P. (1959): Studies on the significance of flies in the transmission of poliomyelitis. The composition of blowfly fauna in defferent parts of Finland during the year 1958. - Annales Entomologici Fennici 31: 137-162.

Povolný D. (1979): Některá hlediska praktického využití hmyzu v kriminalistice. - Kriminalistický sborník 10: 620-630.

Rognes K. (1991): Blowflies (Diptera, Calliphoridae) of Fennoscandia and Denmark. - Fauna entomologica Scandinavica 24: 1-272.

Rognes K. (2013): Fauna Europaea: Calliphoridae In: Pape T. \& Beuk P. (eds): Fauna Europaea: Diptera, Brachycera. Fauna Europaea version 2.6. http://www.faunaeur.org, most species data not modified since 2010. Accessed 01.10.2013.

Schroeder H., Klotzbach H. \& Püschel K. (2003): Insects‘ colonization of human corpses in warm and cold season. - Legal Medicine 5: 372-374.

Smith K.G.V. (1986): A manual of forensic entomology. Comstock Publishing Associates, Cornell University Press, Ithaca, NY, 205 pp.

Šuláková H. (2006): Speciální biologie: využití hmyzu při stanovení post mortem intervalu. - Kriminalistický sborník 3: 36 - 37.

Wyss C., Cherix D., Michaud K. \& Romain N. (2003): Pontes de Calliphora vicina, Robienau-Desvoidy et de Calliphora vomitoria (Linné) (Dipteres, Calliphoridae) sur un cadavre humain enseveli dans la neige. Revue internationale de crimilologie et de police technique et scientifique 56(1): 112-116.

\section{Vliv zmražení na počáteční kolonizaci kadáveru zástupci nekrofágních organismů}

Tato studie byla zaměřena na zjištění, zda zamražení kadaveru před samotnou volnou expozicí ovlivňuje druhové složení dvoukřídlých a rychlost kolonizace při volné expozici. Při dvou experimentech byly použity kadávery kura domácího (Gallus gallus f. domestica L.) o hmotnosti cca 1,5 kg, které byly všechny usmrceny stejným způsobem, avšak polovina byla před volnou expozicí zmražena. Kadávery byly exponovány v městě Smečno, Středočeský kraj, v červnu a červenci 2013. Výsledky experimentu prokázaly, že předem zmražený i čerstvý kadáver kolonizují stejní zástupci bzučivek (Diptera, Calliphoridae). Během pokusů byly zjištěny druhy Calliphora vicina Robineau-Desvoidy, 1830, Lucilia sericata (Meigen, 1826), Lucilia illustris (Meigen, 1826), Lucilia ampullacea Villeneuve, 1922, Phormia regina (Meigen, 1826) a Protophormia terraenovae (RobineauDesvoidy, 1830). Procentuální zastoupení jednotlivých druhů bylo při obou variantách shodné. Zmražený a čerstvý kadáver se lišily v celkovém počtu jedinců (larev), kteří se na zvířatech vyvíjeli, a ve způsobu, jakým se kadávery rozkládaly. Součástí diskuze je zhodnocení využití dosavadních výsledků v kriminalistické praxi.

Authors’ addresses: Hana Šuláková, Institute of Criminalistics Prague, P.O. Box 62/KUP, Strojnicka 27, CZ-170 89 Prague 7; Czech Republic. E-mail: sulakova@centrum.cz

Lucie Harakalová, Miroslav Barták, Department of Zoology and Fisheries, Faculty of Agrobiology, Food and Natural Resources, Czech University of Life Sciences, CZ-165 21 Praha 6 - Suchdol, Czech Republic. E-mail: luciehar@seznam.cz, bartak@af.czu.cz 